\title{
Studying Distance Students: Methods, Findings, Actions
}

\author{
Diane Wahl \\ Beth Avery \\ Lisa Henry \\ University of North Texas
}

\begin{abstract}
University of North Texas (UNT) Libraries began studying the library needs of distance learners in 2009 using a variety of approaches to explore and confirm these needs as well as obtain input into how to meet them. Approaches used to date include analysis of both quantitative and qualitative responses by online students to the LibQUAL+ surveys over time, focus groups, observations and interviews. The Libraries administered the LibQUAL+ survey and conducted focus groups. The Libraries then worked with two graduate level qualitative analysis classes, one on campus and one online, to do further study that included additional focus groups, observations, and interviews. The effectiveness, strengths and problems encountered with each method, as well as with the technology used in executing them, are covered. Triangulation of the results of the various methods to confirm findings is discussed as are the actions that are being taken to address the findings.
\end{abstract}

\section{Introduction}

In 2005, the University of North Texas (UNT) Libraries began administering the LibQUAL+ survey, joining many educational institutions which were asking their user communities for input on improving services. Although this survey provided very useful information regarding areas of user satisfaction and dissatisfaction, it was often not obvious what actions to take in response, even after analyzing the comment data collected by the survey. A decision was made in spring of 2009 to compliment the survey data with qualitative and ethnographic research.

Online students were chosen for study for several reasons. Increasing numbers of students are enrolling in online classes: Approximately nine percent of UNT's 36,000 students are online only. Additionally, many on campus students prefer to use the library's online services and resources, and in fact, have the same needs as distance students. For example, UNT has many commuter students who live throughout the Dallas/Fort Worth metroplex. In addition to the distance they must travel, these students often have jobs or families or both, making it difficult to come to campus other than for class. So while they may be taking classes on campus and may be able to make occasional use of the physical library, their use of the library is primarily the way distance students must use the library. The following comments were made on the 2009 LibQUAL+ survey by students who identified the library most often used as "UNT online library services":

- I don't use the physical library on campus, but the online resources are excellent. The only problem I have ever had is with journal articles only being available at the actual library. Commuting from Plano makes it difficult to access those articles as I am only on campus 1-2 nights per week and only get there from work just in time for class.

- Thank you for the valuable online resources.! [sic] I am very busy and generally do not have time to physically visit the on-campus library.

Considering this data, we thought that if library services improve for online students, they will also improve for on campus users. 
Additionally, a number of ethnographic studies of the needs of college and university students have recently been conducted, including work done at the University of Rochester (Foster \& Gibbons, 2007), at Loughborough University (Bryant, 2007), at MIT (Gabridge, Gaskell, \& Stout, 2008), at the University of Dayton (Webb, Schaller, \& Hunley, 2008), at Fresno State (Delacore, Mullooy, \& Scroggins, 2009), at CUNY (Smale. \& Regalado, 2010), at a group of Illinois academic libraries (Duke \& Asher, 2011), and at Brigham Young (Washburn \& Bibb, 2011). However, none of these studied the library needs of distance learners.

Qualitative and ethnographic work is being done with distance learners. Online focus groups with distance learners have been conducted via teleconference at Athabasca University (Schafer, 1998), and using a chat room at the University of Nevada, Las Vegas (Grays, Del Bosque, \& Costello, 2008). At the 2011 American Library Association Annual Conference, the LITA Distance Learning Interest Group presented a panel discussion with four speakers discussing their experience doing qualitative studies online. Three of the panelists, representing Oregon State (Buck, 2011), the University of Maryland (Mann, 2011), and UNT (Wahl, 2011) discussed their unpublished work with online focus groups. The fourth speaker, Janet Salmons discussed her book on conducting qualitative research online using interviews (Salmons, 2010). The focus of the book was on methods and it did not address library services for distance learners. She has since published another book on conducting online interviews, but it also does not address library services for distance learners (Salmons, 2011). Therefore, an additional goal of our work is to provide guidance regarding what did and did not work for others who want to study their distance learners.

\section{Methods and Results}

\section{LibQUAL+ Survey Statistics and Comments}

The first method used to study distance learners was an analysis of the spring 2009 LibQUAL+ survey results. From the first time the survey was administered at UNT, the ability to identify distance learners has been a consideration. This goal is achieved by including "UNT online library services" as a response to the question "The library that you use most often." It should be noted that the population that selects this option also includes some on campus users who primarily use online services. However, as pointed out in the introduction, many of these students have the same needs as distance students with respect to access to online library services and resources. The data provided by these respondents was included in the study.

The LibQUAL+ survey was distributed by email to all students and faculty at UNT. This approach to recruiting survey participants results in a convenience sample, which is a sample made up of individuals readily available to the researchers. Other examples convenience samples include people walking through a mall or students enrolled in a class.

Bias is nearly always an issue when using a convenience sample. We assumed that some of those who chose to respond have had positive or negative interactions with the library that they want to discuss further. In order to have a more representative sample population, we addressed various other forms of bias. Selection bias, the exclusion of certain individuals or groups in the population, is a significant issue for the LibQUAL+survey at UNT. Individuals who do not read their email regularly may differ from those who do in their use of the library and their evaluation of the services provided. Additionally, many students miss the email because they prefer to use outside email accounts, rarely check their university account, and do not forward their university account to their preferred account. All of these groups of students also may differ from each other in their use and evaluation of library services. Non-response bias is another form of bias that is an issue for any survey. Individuals may see the survey but fail to respond. This population may represent significant differences from those who see and take the survey (Freedman, 2004, p. 986-990).

We addressed bias in a number of ways. To increase the number of individuals in the population who actually see the survey, we used several approaches, including placing links to the survey on frequently used pages of the library website, placing links on the desktops of library and general access lab computers, and distributing paper and electronic flyers with the survey URL around the campus. Of these 
approaches, the website links provide an alternative way to reach distance learners. In the case of survey nonresponse, sending multiple email reminders and offering incentives have both been shown to increase the representativeness of samples (Vehovar, 2002). UNT uses both of these techniques. When selecting incentives, shipping costs and the need to choose something that can be used easily by a distance student are always considerations. For example, gift certificates to local businesses could not be used by most distance students.

In addition to the standard set of LibQUAL+ questions, UNT also has selected five local questions that have been used in all of the surveys except the one in 2008 when UNT Libraries participated in the LibQUAL+ Lite pilot. They are included here because some of them are identified as important issues in the analysis of survey results:

- LQ-1 Availability of online help when using my library's electronic resources.

- LQ-2 Teaching me how to access, evaluate, and use information.

- LQ-3 Making me aware of library services.

- LQ-4 Online course support (readings, links, references).

- LQ-5 Timely delivery of the articles and documents that I need.

The survey asks respondents to score items related to various aspects of library service by providing their minimum acceptable, desired, and perceived levels of service. These responses were used to examine priorities, superiority gaps, and adequacy gaps.

Priorities were identified by looking at the items that had the highest desired levels of service. This data tells us what is most important to our users. Then we examined how our respondents rated library performance by looking at the superiority gaps, which reflect the difference between what the user desires and what s/he perceives is currently received. The superiority gap is calculated by subtracting the desired score from the perceived score. The result is usually negative. A small negative superiority gap for an item indicates that the library is providing service close to what is desired for that item. A large negative superiority gap is indicative of a library's failure to provide the desired level of service. A positive superiority gap means that the library's service exceeds user desires.

Next we considered the adequacy gap, which reflects the difference between a user's minimum requirements for a service and perceived levels of service. The result is usually positive. A large positive adequacy gap indicates that the library is providing service well above the minimum requirements for that item. A small positive superiority gap is indicative of library services barely above the minimum requirements. A negative superiority gap means that the library's service is below the minimum requirements.

The superiority gap and adequacy gap analyses resulted in the same five items being identified as problems by online users, both with respect to living up to desires and meeting minimum standards (see Table 1). Four of these five items are also identified as the highest priorities by online users.

Comment data was also analyzed, using Atlas.ti (http://www.atlasti.com/features.html). Atlas.ti is a qualitative analysis tool that can accommodate text, image and video. It was already being used on the UNT campus and is the tool that members of ARL's Statistics and Assessment staff use when discussing analysis of LibQUAL+ comment data. In analyzing the data, most comments were assigned a code associating it with one of the LibQUAL+ questions. Additional codes were included based on more specific subject content. For example, one of the more specific subject codes is distance learning. This approach allows qualitative data to be considered along with the quantitative data when analyzing results for specific questions. It also provides easy access to comments and portions of comments that deal with a wide variety of topics more specific than the questions. 
Table 1

2009 LibQUAL+ Survey Results

\begin{tabular}{|c|c|c|}
\hline \multicolumn{3}{|c|}{ PRIORITIES } \\
\hline $\begin{array}{c}\text { Item } \\
\#\end{array}$ & Item Description & 2009 Rank \\
\hline IC-1 & Making electronic resources accessible from my home or office & $1(8.55)$ \\
\hline IC-4 & The electronic information resources I need & $2(8.52)$ \\
\hline IC-2 & A library Web site enabling me to locate information on my own & $3(8.49)$ \\
\hline IC-8 & Print and/or electronic journal collections I require for my work & $4(8.49)$ \\
\hline IC-6 & Easy-to-use access tools that allow me to find things on my own & $5(8.4)$ \\
\hline \multicolumn{3}{|c|}{ LARGEST SUPERIORITY GAPS } \\
\hline $\begin{array}{c}\text { Item } \\
\#\end{array}$ & Item Description & 2009 Rank \\
\hline IC-2 & A library Web site enabling me to locate information on my own & $1(-1.43)$ \\
\hline IC-6 & Easy-to-use access tools that allow me to find things on my own & $2(-1.3)$ \\
\hline LQ-1 & Availability of online help when using my library's electronic resources & $3(-1.27)$ \\
\hline IC- 8 & Print and/or electronic journal collections I require for my work & $4(-1.17)$ \\
\hline IC-4 & The electronic information resources I need & $5(-1.15)$ \\
\hline \multicolumn{3}{|c|}{ LARGEST ADEQUACY GAPS } \\
\hline $\begin{array}{c}\text { Item } \\
\#\end{array}$ & Item Description & 2009 Rank \\
\hline IC-2 & A library Web site enabling me to locate information on my own & $1(0)$ \\
\hline IC-8 & Print and/or electronic journal collections I require for my work & $2(0)$ \\
\hline IC-6 & Easy-to-use access tools that allow me to find things on my own & $3(0.05)$ \\
\hline LQ-1 & Availability of online help when using my library's electronic resources & $4(0.19)$ \\
\hline IC-4 & The electronic information resources I need & $5(0.23)$ \\
\hline
\end{tabular}

Comment data provided some context and insight about the need for changes to services or additional services that did not show up in the analysis of the quantitative data and reinforced the need for additional research:

- I am an online student and while the online library is probably very good (and probably deserves higher marks than I gave it above). I do not know how to use it and don't think that I've ever really been made very aware of it (until now).

- I have not been introduced to the library or library services. I have found that the internet and my company library give me what I need. By the way, I have yet to see a link to the libray [sic] on any of the pages I visit. It is not on web CT [sic] that I can see. In short, Where [sic] is it? If a person who is predominently [sic] an on-line [sic] student has to look for a library services link and the link to is not on the pages visited regularly then the library does not exist. It's the old saw, "Location, Location, Location."

\section{LibQUAL+ Survey Statistics and Comments}

In the spring of 2011 the LibQUAL+ survey was again administered. Online student priorities, superiority gaps and adequacy gaps were again reviewed and were compared to the 2009 results (see Table 2). Several changes emerge from 2009 to 2011. Examination of priorities shows an increasing emphasis on items that reduce the time required to complete library research. The five items identified as the highest priority show what is important to them: 
1. Working from home or at the office.

2. A website that is easy (i.e., quick, easy to use).

3. Ability to access information resources quickly without help.

4. Quick delivery of items in storage or borrowed from other libraries.

5. Ready access to important journals in their field.

Table 2

Comparison of 2009 and 2011 LibQUAL+ Survey Results

\begin{tabular}{|c|c|c|c|}
\hline \multicolumn{4}{|c|}{ PRIORITIES } \\
\hline Item & Itom Docrintion & 2011 & 2009 \\
\hline \# & Item Description & Rank & Rank \\
\hline IC-1 & Making electronic resources accessible from my home or office & $1(8.59)$ & $1(8.55)$ \\
\hline $\mathrm{IC}-2$ & A library Web site enabling me to locate information on my own & $2(8.49)$ & $3(8.49)$ \\
\hline IC-7 & Making information easily accessible for independent use & $3(8.38)$ & \\
\hline LQ-5 & Timely delivery of the articles and documents that I need & $4(8.38)$ & \\
\hline IC-8 & Print and/or electronic journal collections I require for my work & $5(8.37)$ & $4(8.49)$ \\
\hline $\mathrm{IC}-4$ & The electronic information resources I need & & $2(8.52)$ \\
\hline IC-6 & Easy-to-use access tools that allow me to find things on my own & & $5(8.4)$ \\
\hline \multicolumn{4}{|c|}{ LARGEST SUPERIORITY GAPS } \\
\hline Item & \multirow{2}{*}{ Item Description } & 2011 & 2009 \\
\hline \# & & Rank & Rank \\
\hline LQ-4 & Online course support (readings, links, references) & $1(-1.01)$ & \\
\hline IC-6 & Easy-to-use access tools that allow me to find things on my own & $2(-1)$ & $2(-1.3)$ \\
\hline LQ-3 & Making me aware of library services & $3(-1)$ & \\
\hline IC-2 & A library Web site enabling me to locate information on my own & $4(-0.99)$ & $1(-1.43)$ \\
\hline $\mathrm{IC}-4$ & The electronic information resources I need & $5(-0.93)$ & $5(-1.15)$ \\
\hline LQ-1 & $\begin{array}{l}\text { Availability of online help when using my library's electronic } \\
\text { resources }\end{array}$ & & $3(-1.27)$ \\
\hline \multirow[t]{2}{*}{ IC-8 } & Print and/or electronic journal collections I require for my work & & $4(-1.17)$ \\
\hline & \multicolumn{3}{|l|}{ LARGEST ADEQUACY GAPS } \\
\hline Item & Itam Deccrintion & 2011 & 2009 \\
\hline \# & Item Description & Rank & Rank \\
\hline LQ-4 & Online course support (readings, links, references) & $1(-0.06)$ & \\
\hline IC-1 & Making electronic resources accessible from my home or office & $2(0.14)$ & \\
\hline LQ-3 & Making me aware of library services & $3(0.19)$ & \\
\hline IC-5 & Modern equipment that lets me easily access needed information & $4(0.24)$ & \\
\hline IC-6 & Easy-to-use access tools that allow me to find things on my own & $5(0.26)$ & $3(0.05)$ \\
\hline IC-2 & A library Web site enabling me to locate information on my own & & $1(0)$ \\
\hline IC-8 & Print and/or electronic journal collections I require for my work & & $2(0)$ \\
\hline LQ-1 & $\begin{array}{l}\text { Availability of online help when using my library's electronic } \\
\text { resources }\end{array}$ & & $4(0.19)$ \\
\hline IC-4 & The electronic information resources I need & & $5(0.23)$ \\
\hline
\end{tabular}

The students are communicating that speed and efficiency in the research process is important to them. Examination of the population provides insight into this point. Thirty-two percent of UNT's graduate students take only online classes; sixty-eight percent of UNT's students enrolled exclusively in 
online classes are graduate students. Additionally, fifty-nine percent of UNT's survey respondents who chose "UNT online library services" in the 2011 LibQUAL+ survey were graduate students. These students are older and are more likely to have jobs and families that compete with their academic programs for time.

When looking at the adequacy and superiority gaps, which identify areas with the highest levels of dissatisfaction, two items from the local questions used at UNT come up for the first time as significant problem areas:

- LQ-3 Making me aware of library services.

- LQ-4 Online course support (readings, links, references).

These items suggest that one way distance students and other online users are asking us to help them save time is by pushing information out to them rather than expecting them to pull that information for themselves.

\section{Online Focus Groups}

The 2009 analysis of LibQUAL+ survey data was followed in the summer of 2009 by focus groups made up of distance students. The first step was to obtain an IRB approval for the focus groups. Without this step, research results cannot be used for presentations and publications. More importantly, it requires putting together a plan up front for how the research will be conducted.

When considering how to recruit for the focus groups, we decided to use non-probabilistic sampling, a type of sampling based on identifying "specific groups of people who either possess characteristics or live in circumstances relevant to the social phenomenon being studied. Informants are identified because they will enable exploration of a particular aspect of behavior relevant to the research" (Mays \& Pope, 1995, p. 110).

Two separate groups of volunteers were recruited using different approaches to recruiting. The library and information science program at UNT uses distance learning extensively with geographically oriented cohorts located around the United States. These cohorts receive only one hour of face-to-face training, provided during an intensive four day institute on campus. The remaining course work is completed online with the three core courses being taken together by members of the cohort. For at least one of those courses there is an embedded librarian who provides additional training. Volunteers from one of these cohorts were solicited using an email sent from the faculty liaison to the cohort. Five volunteers responded and participated together in a focus group limited to this group of volunteers.

The larger group of volunteers was recruited by posting a flyer in Blackboard, the online classroom environment used at UNT. The flyer would pop up on all student homepages the first time each student signed in following the posting. It would then remain accessible in a list of campus announcements on the student homepages for a specified period of time. The flyer described the purpose of the focus group and the type of students desired as volunteers, provided a high level schedule, and offered flash drives as incentives for all volunteers who actually participated in the focus groups. These volunteers were asked to contact one of the researchers by email. The researcher responded with a request for the volunteers to provide the following demographic information about themselves: graduate or undergraduate; college/school enrolled in (UNT has twelve colleges and schools, five of which offer online undergraduate and/or graduate degree programs.); country (if outside of the United States), state (if other than Texas) or hometown; over or under 30 years of age; point in UNT degree (beginning, middle, or near graduation), and gender. The non-probabilistic sample was developed by analyzing the responses received.

This approach turned out to be an effective way to recruit distance students. In twenty-four hours during "Maymester", a compressed semester between the spring and summer semesters, approximately three times as many students as we needed for the focus groups responded to the flyer. It turned out to be important that the initial pool was as large as it was because attrition became an issue once we responded 
with our request for demographic information and continued through the process of scheduling for the focus groups.

In putting together the focus groups, the demographics of the students who responded back were analyzed and students were selected based on these characteristics. Eleven students from this pool followed through and participated in the focus groups. The final pool of students who actually participated in the focus groups drawn from both recruiting methods included sixteen volunteers representing the four largest of the five colleges that offer online degree programs. There were nine graduate students, five undergraduates, one individual enrolled in a graduate level certificate program, and one student with a bachelor's who was taking courses and considering a graduate degree. Four were on campus; three, in the Dallas Fort Worth metroplex; two, in other parts of Texas; six, out of state; and one, out of the country. Five were male; eleven, female. Most were over 30 years old. Fourteen were Caucasian; one, African American; and one, Asian American. One foreign student, not the person who was out of the country, participated. This group of volunteers, although not statistically representative, included factors that were important to this research, including the colleges that place the most emphasis on distance learning, geographic diversity, and diversity in the degree level of the students.

When scheduling the focus groups, students were sent emails with several proposed dates and times and asked to respond with all proposed sessions that they could attend. Focus groups were scheduled based on these responses. In the future, a web-based scheduling tool such as Doodle (www.doodle.com) will be used as it compiles the responses for you, making scheduling faster and easier.

As already noted, attrition continued during the scheduling process and through the conduct of the focus groups. In some cases, if someone missed a scheduled session, we were able to reschedule her/him in another group. However, not everyone agreed to reschedule. Ultimately, the number of focus group participants dropped from 23 to 16 during this phase. Four separate sessions were conducted, each with different participants.

When developing the questions to ask the focus group, the issues identified in the LibQUAL+ survey were consulted. In addition, library staff members who provide services to distance students were asked to suggest questions. Inclusion of library staff in the planning is important because their buy in is important if they are going to consider changes to current services based on focus group results.

The technology used for conducting the online sessions can impact the flow and effectiveness of the session. Dimdim (www.dimdim.com), recently acquired by Salesforce (www.salesforce.com) and is no longer available, was initially used because it provided simultaneous conference and chat capabilities, and recorded both. However, funding limitations meant that the free version had to be used, which allowed only three participants to be authorized to speak at the same time. As a result, the focus group facilitators had to change authorization for speaking regularly during the sessions, which distracted them from the content of the discussion. An examination of Microsoft's Netmeeting revealed that it had both the same capabilities and the same liabilities. Ultimately, a low cost conference call service available through the university was used. It provided recordings of the calls and the calls were supplemented with the chat capabilities in Dimdim. Use of the chat capabilities varied significantly between groups. Some did not use them at all while others groups had comments and supplementary information added throughout the session. The reason for this inconsistency was the variation in the way different participants chose to communicate. A broader array of tools for online meetings is becoming available, both open access and proprietary licensed to universities. Regardless of the tool that is used, the important factor is to make sure that operating it does not distract the focus group facilitator(s) or that a separate person handles the technical aspects of the software.

The recordings for these focus groups were transcribed, initially with participant names included. After the transcriptions were completed, a set with participant names replaced by descriptive codes, typically referencing the subject studied by the participants, was created. Examples include MLS female, Emergency Management male, and Applied Technology male. The anonymous transcription was then entered into Atlas.ti (http://www.atlasti.com/features.html). In a manner similar to the analysis LibQUAL+ comment data, each comment was coded based on the question to which it was a response and also based 
on the subject content. This approach allows easy review of all responses to each question in the focus group script. It also provides easy access to comments and portions of comments that deal with a wide variety of topics more specific than the questions.

The first step in responding to the results was for the focus group facilitators to read through the coded results and identify the key issues. Then a committee was put together made up of individuals who were in a position to both understand and address the issues. Members included the head of Research and Instructional Services; the manager/designer of the library website; a representative from the Center for Learning Enhancement, Assessment, and Redesign (CLEAR), the campus organization that manages the online learning environment, Blackboard; a faculty member from the Department of Library and Information Science in the College of Information; the distributed learning liaison for the library; and subject librarians to several departments represented in the focus groups.

After an initial review and agreement regarding key issues, the committee broke into four subgroups based on the following issues: marketing library services, library instruction for online students, Blackboard, and the library website. The identification of these issues masks a driving factor behind all of them: two of the sixteen focus group participants indicated that until they saw the flyer about the focus groups, they were unaware that the library provided online services and resources. This fact echoes the student comments quoted from the 2009 LibQUAL+ survey.

The subgroups made the following recommendations on how to improve services in their assigned area. Those that have been or are being implemented are noted:

1. Increase the Libraries' presence and visibility in Blackboard:

a. Add library links to My Blackboard and to the Blackboard sign on page. Create a library gateway on the sign on page. (Note: A link to the Libraries now appears as a book mark under Campus Bookmarks on the Blackboard homepage).

b. Provide an entry page, which would be a one-stop shop for library resources/services, on the library website with information on and links to online services and resources. Include a link to this page from the new library gateway on Blackboard. (Note: In development).

c. Create an attractive and self-explanatory icon for the online library services, and place the icon at applicable locations to attract and increase online users' attention.

d. Use the Blackboard Announcements to publicize library collections and services. The announcements can be directed to departments, faculty, students, other groups, to keep people from having to sift through items of no relevance to them. (Note: This tool is now being used, but infrequently, and more to publicize events and surveys than collections and services. Plans are being made to increase its use to market collections and services).

2. Provide library instruction opportunities to online students that don't require being at the physical library:

a. Build an online users guide to the Libraries in Blackboard. Design it in such a way that a student can access an orientation type overview of library services or can key in on short, 5 minutes or less instructional segments focusing on specific services, tools, etc. Consider using podcasts or vodcasts stored at iTunes U. (Note: In development).

b. Establish discipline specific "office hours" staffed by subject specialists for the various disciplines on a weekly basis, using instant messaging or other technology. Focus group feedback on what technology students would like to work with would be appreciated. (Note: This service was attempted for one semester but received little response. This may have been because of lack of publicity by the faculty to their classes. It may be reconsidered). 
c. Develop a research paper calculator in Blackboard. This tool will allow a user to enter their research project due date and get a schedule of activities and when they need to be finished in order to complete the assignment on time. Over time, links to modules providing information about how to perform the various activities will be added. Here are some examples of calculators in use at other universities: http://mulibraries.missouri.edu/guides/assigncalc.htm (Note: The current website does not allow embedding of this type of calculator. It will be considered in the website redesign discussed in a later section).

3. Make the UNT Libraries' website easier to search. Ensure that terminology used on library web pages includes keywords likely to be used in a Google search for information on the topics covered by the web pages. This activity will involve training web page creators and then having them use what they have learned to improve the searchability of their web pages. (Note: In development).

4. Publicize and provide online instruction in using search software that looks for information on a specified topic in a variety of databases, including the library catalog, simultaneously. (Note: A web scale discovery service is currently being implemented, to replace a federated search engine that was made available in 2010 to address this point).

5. Communicate and collaborate more effectively with faculty members that teach online classes.

a. Provide appropriate library information, including links, in the course syllabus template.

b. Communicate with/instruct faculty on the value of maintaining library information in their syllabi. Communication should be both general (e.g., Blackboard announcements directed to faculty, listserv announcements) and specific (e.g., One on one discussions between faculty and CLEAR instructional consultants or faculty and subject librarians). (Note: CLEAR is working with faculty on this issue).

c. Collaborate with faculty in development of their unique course syllabi, emphasizing the role of library resources for online classes and resulting in customized pages for the specific classes that are library gateways to the content needed for the classes. (Note: Class pages have been developed for a number of classes. We are currently working with faculty to see that links to the pages are added to the Blackboard class pages in addition to appearing on the library website, where they are currently located).

One of the most important outcomes of this process was a change in the library's relationship with CLEAR. UNT Libraries had long had links in the class page template in Blackboard. However, many faculty members removed some or all of the template content, including the library link. As a result, a link was needed in a more general location not tied to a class page. Efforts to make this happen had been unsuccessful. However, students repeatedly brought up the issue during the focus group sessions:

- I wish there were more mention of the UNT Library on the main UNT page, or my UNT page, or in VISTA so that way I'm--or WebCT Blackboard so that way I don't have to go to any course to look at that library. It should just pop out right there.

- I kind of pictured when I started the Blackboard kind of was a deal [sic], that was my portal to the whole online distance thing, and discovered that that wasn't what it really was. So I kind of had wondered sometimes, if they were working towards that where they would have that kind of a resource because that would be a good idea [sic].

- This has been quite an interesting discussion because I'm finding out all these resources that I could have accessed while I was a student there if I had only known, and I think, personally, Diane, I think the starting point is getting the library icon on Blackboard. As a distance learner, if you want people to access and utilize your services, which is what I understand this whole discussion to be about-how can we improve it--get it at the starting point and get that virtual tour and/or tutorial on there and advertise yourself. Let 
everybody know what services you provide. As a distance learner we are, pretty much, like I said, coming through the back door or the window. We don't know.

Instead of a committee of librarians summarizing these comments in a report to send to CLEAR, there was a representative of CLEAR on the committee who read these statements for herself. She was in the group that made recommendations related to Blackboard. Work with CLEAR to improve library access for distance learners is continuing. A library tab within Blackboard is under development which will provide many of the additional features the focus group participants requested.

\section{Ethnographic Study by Graduate Level Ethnographic and Qualitative Methods Classes: Focus Groups, Observations, Interviews}

In the fall of 2010, UNT Libraries partnered with Lisa Henry, a faculty member in the Anthropology Department who was teaching two qualitative analysis classes: one on campus and one online. The agreement was for the class project for each class to be a study of the library needs of distance learners. Each class would use three methods: focus groups, observations, and interviews.

A convenience sample was used for this project. Volunteers were solicited via emails sent to a mailing list made up of students taking at least fifty percent of their coursework online. Not enough students volunteered to provide the number of subjects required for the class projects. One factor in the number of volunteers may be the fact that the class had no funding for incentives. The use of email for recruiting may be another reason. The student researchers did send out at least two emails to the names on the mailing list. Students being recruited may not have been checking their university emails. As a result, another strategy was used to recruit participants. CLEAR posted an announcement on Blackboard that went to everyone who had to go to Blackboard for any course. In addition, some faculty made announcements in classes, and some of those faculty members offered extra credit for participation. Ultimately, the plan for the research changed. The online class maintained its focus on distance learners, and the distance learner respondents were reserved for them. The on campus class changed its focus to the use of online resources by on campus students. An important factor in the success of this project was the willingness to be flexible and make changes as needed. In the introduction, it was suggested that improving library services for distance learners might improve them for on campus students as well. This change provided an opportunity for a direct comparison of the needs of these two groups.

The sample studied by the online class consisted of fifty-seven students, including fifteen lower level undergraduates, nineteen upper level undergraduates, thirteen master's students, and ten doctoral students representing six colleges and schools, including four with online degree programs. Some colleges offer online classes but do not have online degree programs.

The on campus sample consisted of thirty students, including three lower level undergraduates, fifteen upper level undergraduates, and twelve graduate students. Six colleges and schools were represented, duplicating only three of the colleges included in the online class sample.

The on campus students were able to conduct their research face-to-face. However, the online students had the challenge of using technology to facilitate their research. They used Live Classroom, now Blackboard Collaborate: http://www.blackboard.com/Platforms/Collaborate/Products/BlackboardCollaborate/Web-Conferencing.aspx), which accommodates voice communication and text chat and can be archived to allow transcriptions to be created. It also supports application sharing, including allowing the interviewer to give control to the student being observed so that the interviewer can see how the student conducts research on the UNT website or using internet tools.

After their project was complete, the student researchers noted that in the future they would handle interviews with students differently. They observed that students often did not have a clear memory after the fact of problems encountered performing online research. As a result, they recommended that interviews of this type be conducted either during an observation or immediately following an observation of the interviewee performing research. 
Each class made recommendations based on their findings (Henry et al., 2010a; Henry et al., 2010b). Comparisons of the results exhibit a remarkable consistency, in spite of the fact that the online class was focusing on online students and the on campus class was focusing on students taking classes on campus (see Table 3). This consistency validates the hypotheses that improving services for online students will also improve them for on campus users.

Table 3

Comparison of Online and On Campus Anthropology Class Recommendations

Online Class On Campus Class

\section{Improve user experience with the UNT}

Libraries website. We recommend working with the design department to make the website more visually attractive, to simplify the website design, to create an integrated search tool (much like Google Scholar), and to create the possibility for students to personalize the library website for their needs.

Improve library instruction. We recommend further collaborations between the library and professors and tiered levels of training. Google is making people overconfident because it is forgiving of poor search terms. For this reason we recommend offering basic tutorials and more advanced tutorials (such as how to perform a successful search, and tutorials for new research projects). Tutorials should be quick and interesting video tutorials.

Improve communication. Even though many resources for instruction are available to students on the UNT Libraries website, students do not know about them. We recommend creating a printout catalog of the site that would include explanations of different databases and what those databases can be used for. We also recommend more publicizing of the library URL and the tutorials.

\author{
Improve user experience with the UNT \\ Libraries website. We recommend working with \\ the design department to simplify the website \\ design and create an integrated search tool, much \\ like Google Scholar.
}

Improve library instruction. We recommend further collaborations between the library and professors. Students need instruction on how to use the library electronic resources closer to the time their research assignment is introduced. They need tailored and specific information on which databases are best for their discipline. They are not reading the content that currently exists on the website. We recommend also making video tutorials that are quick and interesting.

Improve Communication. Even though many resources for instruction are available to students on the UNT Libraries website, students do not know about them. We recommend writing enewsletters with library updates. We also recommend highlighting the department librarians so that students know they are a resource for research.

An important factor in this approach is that it was conducted by non-librarians. During the planning stages, the student researchers met twice with a librarian to ask questions about what the Libraries wanted to know about distance students. Otherwise, the classes planned and conducted the research on their own. This element made the results of particular interest because they were not affected by any preconceived ideas held by library staff.

\section{Triangulation}

Triangulation, using multiple methods or different researchers or both to examine an issue, is a way to confirm results. It is frequently used when trying to understand the complexity of human opinion 
and behavior (Cohen, Manion, \& Morrison, 2003). Since English is an imprecise language and librarians often use jargon not used by the patron, in cross comparison of the studies standardized terminology was used to combine concepts about services.

A comparison of the results of the focus groups and the ethnographic study done by the UNT graduate students in anthropology supports the interpretation of the changes evidenced in the two LibQUAL+ surveys (see Table 4). All four studies show online students asking for an easier to use website and easier to use search tools.

Table 4

Comparison of the Results of from All Methods

\begin{tabular}{|c|c|c|c|}
\hline $\begin{array}{c}\text { LibQUAL+ } \\
\text { 2009 Top } \\
\text { Five } \\
\text { Superiority } \\
\text { Gaps }\end{array}$ & 2009 Focus Groups & 2010 Ethnographic Study & $\begin{array}{c}\text { LibQUAL+ } \\
2011 \text { Top } \\
\text { Five } \\
\text { Superiority } \\
\text { Gaps }\end{array}$ \\
\hline \multicolumn{4}{|c|}{ Make the library website and access tools easier to use successfully } \\
\hline $\begin{array}{l}\text { *IC-2 A } \\
\text { library Web } \\
\text { site enabling } \\
\text { me to locate } \\
\text { information } \\
\text { on my own }\end{array}$ & $\begin{array}{l}\text { Make the UNT Libraries' website } \\
\text { easier to search. } \\
\text { Ensure that terminology used on } \\
\text { library web pages includes } \\
\text { keywords likely to be used in a } \\
\text { Google search for information on } \\
\text { the topics covered by the web } \\
\text { pages. This activity will involve } \\
\text { training web page creators and } \\
\text { then having them use what they } \\
\text { have learned to improve the } \\
\text { searchability of their web pages. }\end{array}$ & $\begin{array}{l}\text { Improve user experience with } \\
\text { the UNT Libraries website. We } \\
\text { recommend working with the } \\
\text { design department to make the } \\
\text { website more visually attractive, to } \\
\text { simplify the website design, to } \\
\text { create an integrated search tool } \\
\text { (much like Google Scholar), and to } \\
\text { create the possibility for students } \\
\text { to personalize the library website } \\
\text { for their needs. }\end{array}$ & $\begin{array}{l}\text { IC-2 A } \\
\text { library Web } \\
\text { site enabling } \\
\text { me to locate } \\
\text { information } \\
\text { on my own }\end{array}$ \\
\hline $\begin{array}{l}\text { *IC-6 Easy- } \\
\text { to-use access } \\
\text { tools that } \\
\text { allow me to } \\
\text { find things } \\
\text { on my own }\end{array}$ & $\begin{array}{l}\text { Publicize and provide online } \\
\text { instruction in using search } \\
\text { software that looks for information } \\
\text { on a specified topic in a variety of } \\
\text { databases, including the library } \\
\text { catalog, simultaneously. }\end{array}$ & & $\begin{array}{l}\text { *IC-6 Easy- } \\
\text { to-use access } \\
\text { tools that } \\
\text { allow me to } \\
\text { find things } \\
\text { on my own }\end{array}$ \\
\hline \multicolumn{4}{|c|}{ Improve instructional resources available to distance learners } \\
\hline $\begin{array}{l}\text { *LQ-1 } \\
\text { Availability } \\
\text { of online } \\
\text { help when } \\
\text { using my } \\
\text { library's } \\
\text { electronic } \\
\text { resources }\end{array}$ & $\begin{array}{l}\text { Provide library instruction } \\
\text { opportunities to online students } \\
\text { that don't require being at the } \\
\text { physical library. } \\
\text { a. Build an online users guide to } \\
\text { the Libraries in Blackboard. } \\
\text { Design it in such a way that a } \\
\text { student can access an } \\
\text { orientation type overview of } \\
\text { library services or can key in } \\
\text { on short - } 5 \text { minute or less - }\end{array}$ & $\begin{array}{l}\text { Improve library instruction. We } \\
\text { recommend further collaborations } \\
\text { between the library and professors } \\
\text { and tiered levels of training. } \\
\text { Google is making people } \\
\text { overconfident because it is } \\
\text { forgiving of poor search terms. For } \\
\text { this reason we recommend offering } \\
\text { basic tutorials and more advanced } \\
\text { tutorials (such as how to perform a } \\
\text { successful search, and tutorials for }\end{array}$ & $\begin{array}{l}\text { *LQ-4 } \\
\text { Online } \\
\text { course } \\
\text { support } \\
\text { (readings, } \\
\text { links, } \\
\text { references) }\end{array}$ \\
\hline
\end{tabular}




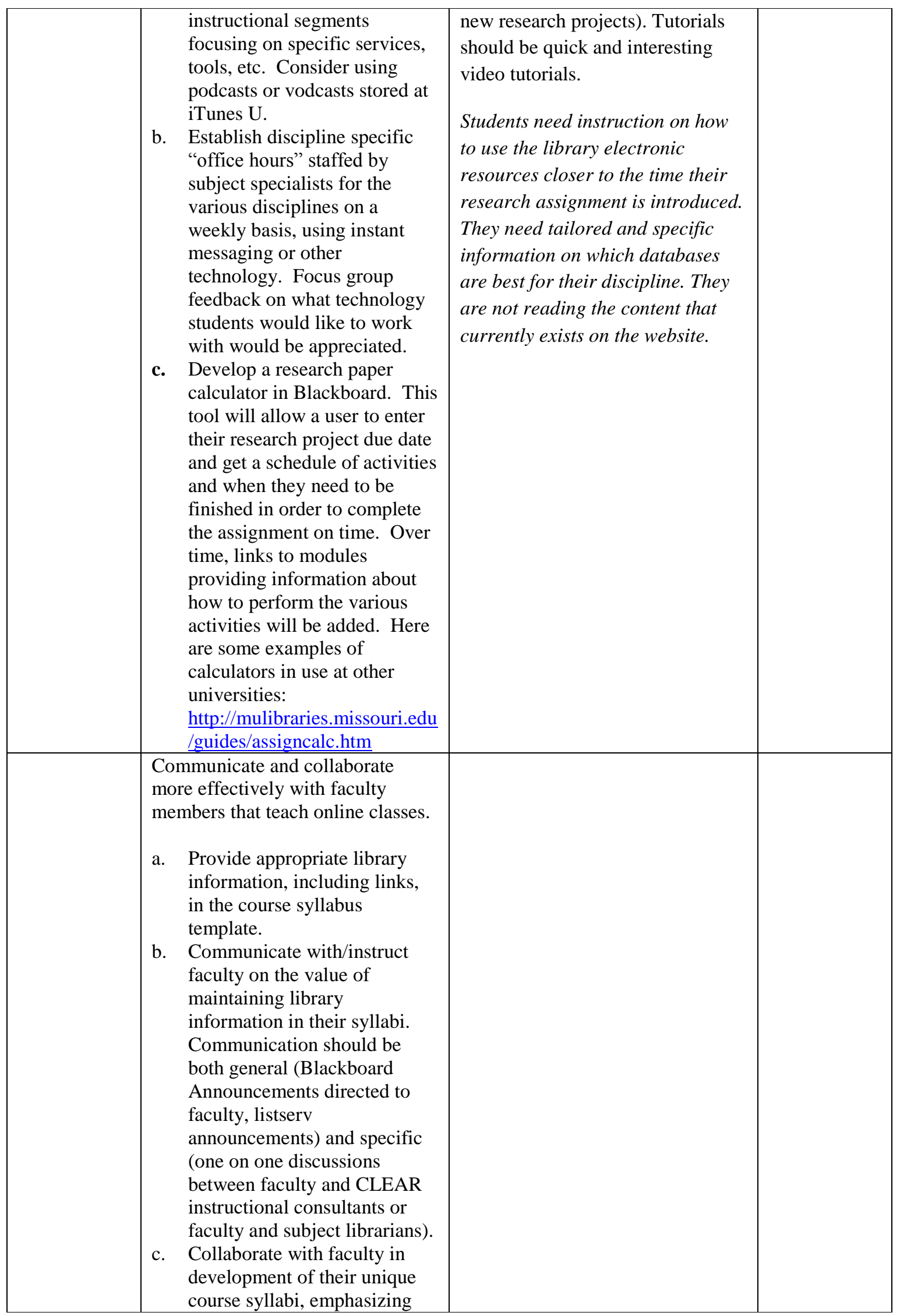




\begin{tabular}{|c|c|c|c|}
\hline & $\begin{array}{l}\text { the role of library resources } \\
\text { for online classes and } \\
\text { resulting in customized pages } \\
\text { for the specific classes that are } \\
\text { library gateways to the content } \\
\text { needed for the classes. }\end{array}$ & & \\
\hline \multicolumn{4}{|c|}{ Improve communication about services and resources } \\
\hline & $\begin{array}{l}\text { Increase the Libraries' presence } \\
\text { and visibility in Blackboard } \\
\text { a. Add library links to My } \\
\text { Blackboard and to the } \\
\text { Blackboard sign on page. } \\
\text { Create a library gateway on } \\
\text { the sign on page. } \\
\text { Provide an entry page (which } \\
\text { would be a one-stop shop for } \\
\text { library resources/services) on } \\
\text { the library website with } \\
\text { information on and links to } \\
\text { online services and resources. } \\
\text { Include a link to this page } \\
\text { from the new library gateway } \\
\text { on Blackboard. } \\
\text { Create an attractive and self- } \\
\text { explanatory icon for the online } \\
\text { library services, and place the } \\
\text { icon at applicable locations to } \\
\text { attract and increase online } \\
\text { users' attention. } \\
\text { Use the Blackboard } \\
\text { Announcements to publicize } \\
\text { library collections and } \\
\text { services. The announcements } \\
\text { can be directed to } \\
\text { departments, faculty, students, } \\
\text { other groups, to keep people } \\
\text { from having to sift through } \\
\text { items of no relevance to them. }\end{array}$ & $\begin{array}{l}\text { Improve communication. Even } \\
\text { though many resources for } \\
\text { instruction are available to students } \\
\text { on the UNT Libraries website, } \\
\text { students do not know about them. } \\
\text { We recommend creating a printout } \\
\text { catalog of the site that would } \\
\text { include explanations of different } \\
\text { databases and what those databases } \\
\text { can be used for. We also } \\
\text { recommend more publicizing of } \\
\text { the library URL and the tutorials. } \\
\text { We recommend writing e- } \\
\text { newsletters with library updates. } \\
\text { We also recommend highlighting } \\
\text { the department librarians so that } \\
\text { students know they are a resource } \\
\text { for research. }\end{array}$ & $\begin{array}{l}\text { *LQ-4 } \\
\text { Online } \\
\text { course } \\
\text { support } \\
\text { (readings, } \\
\text { links, } \\
\text { references) }\end{array}$ \\
\hline & & & $\begin{array}{l}\text { *LQ-3 } \\
\text { Making me } \\
\text { aware of } \\
\text { library } \\
\text { services }\end{array}$ \\
\hline \multicolumn{4}{|l|}{ Other } \\
\hline $\begin{array}{l}* \mathrm{IC}-4 \text { The } \\
\text { electronic } \\
\text { information } \\
\text { resources I } \\
\text { need }\end{array}$ & & & $\begin{array}{l}\text { IC-4 The } \\
\text { electronic } \\
\text { information } \\
\text { resources I } \\
\text { need }\end{array}$ \\
\hline $\begin{array}{l}\text { *IC-8 Print } \\
\text { and/or }\end{array}$ & & & \\
\hline
\end{tabular}




\begin{tabular}{|l|l|l|l|}
\hline electronic & & \\
journal & & & \\
collections I & & & \\
require for & & & \\
my work & & & \\
\hline
\end{tabular}

Note. An asterisk marking LibQUAL+ items in the chart indicates that the item was also one of the top five adequacy gaps in the specified year. The 2010 Ethnographic Study recommendations are taken from the online study; additional data from the on campus study is in italics.

They also all express a need for library instruction. In the 2009 LibQUAL+ survey, respondents ask for "online help when using my library's electronic resources." However, the following summer, focus group feedback resulted in the following recommendations related to library instruction and a more subtle form of instruction, library marketing:

- Emphasis on creating a library presence in Blackboard, including a library portal (user guide) and use of Blackboard to communicate library news of interest to specific groups of students.

- Making subject librarians accessible to online students.

- Collaborating with faculty to develop "library gateways to the content needed for the classes."

Then, in the fall of 2010, the graduate classes in qualitative and ethnographic methods both emphasized pushing information to students by means of library instruction and communication/marketing.

In 2009, they were primarily concerned about the difficulty of finding things. By 2011, they are asking that the Libraries become less passive in providing services.

\section{Additional Responses}

The changes to Blackboard discussed above were made specifically because they benefited distance students. Additional changes are being taken because they are seen as improving library services for all students and faculty, not just for distance students. These changes include the following:

- A federated search engine was implemented in 2010. It is now being replaced by a web-scale discovery service.

- A library website redesign is getting started and significant input is being solicited from users.

- Library liaisons are increasing efforts to build relationships with faculty. The faculty is seen as an important avenue to reaching students.

- A new position, Director of Communications and Marketing, has been established in the Libraries.

These actions taken, in part, as a result of the findings of our study of distance students support the hypothesis that if library services are improved for distance learners, they will be improved for everyone.

\section{Conclusion}

The results of this study show the progression of student thought from the desire for user-friendly online services to their request for help, either by instruction or by effective marketing of services. They illustrate the confirmation of findings that can emerge from using multiple methods to study an issue. Finally, an examination of the way the methods were applied also provides guidelines for conducting this type of research with distance students: 
- Standard surveys such as the LibQUAL+ survey, can be used to study special populations, such as distance learners, if demographic identifiers are included.

- Use of non-probabilistic sampling can provide access to a variety of viewpoints in the relatively small samples used for qualitative and ethnographic studies.

- College students respond to incentives; they can be very important in obtaining enough participants to provide meaningful data, whether the study is quantitative or qualitative.

- When conducting qualitative and ethnographic studies, selection of easy to use technology, or having support personnel present to handle the technology, facilitates the study of online students without becoming a distraction.

- With the right technology, researchers can study things that many would think require face-to-face interaction. For example, they can observe distance learners conducting research using their library website and online tools.

- The findings of studies conducted by researchers who are not members of the organization being studied can be advantageous because they reflect a fresh perspective unbiased by organizational preconceptions.

- When changes are to be made based on research results, change can be facilitated by including representatives of groups likely to be required to make changes identified in the review of research results and in developing recommendations for change based on those results.

The results also highlight the benefits of using this kind of study to provide information to support management decision making. At UNT we have used the committee recommendations and research findings to develop strategic plan goals, as well as projects in support of those goals. This type of research can be conducted in a cost-effective manner. The only part of this research that required additional funding was the focus groups, which required funding for incentives and for transcription. Although there are costs associated with the LibQUAL+ survey, this survey is done regularly and the expenses are already part of the library budget. Using data from this survey for projects such as this one increase the impact and value received from the survey. Finally, there are no expenses associated with the research done by the anthropology classes. However, there are benefits. The student subjects may be more open and honest with other students than they would be with a librarian researcher. The student researchers get professional experience as students and, additionally, many of them indicated that they had learned a lot themselves about using the library. 


\section{References}

Bryant, J. (2007). An ethnographic study of user behaviour in Open3 at the Pilkington Library (Master's dissertation, Loughborough University, Leicestershire, United Kingdom). Retrieved from http://hdl.handle.net/2134/3136

Buck, S. (2011, June). Focus groups with Adobe Connect. Panel slides presented at the 2011 Annual Conference of the American Library Association, New Orleans, LA. Retrieved from http://connect.ala.org/node/137552\#comment-22192

Cohen, L., Manion, L., \& Morrison. K. (2003). Research methods in education. New York: RoutledgeFalmer.

Delcore, H.D., Mullooly, J., \& Scroggins, M. with Arnold, K., Franco, E., \& Gaspar, J. (2009). The library study at Fresno State. Retrieved from http://www.csufresno.edu/anthroplology/ipa

Duke, L.M., \& Asher, A. (Eds.). (2011). College libraries and student culture: What we now know. Chicago: American Library Association.

Foster, N.F., \& Gibbons, S. (Eds.). (2007). Studying students: The undergraduate research project at the University of Rochester. Chicago: Association of College and Research Libraries.

Freedman, D.A. (2004). Sampling. In M. S. Lewis-Beck, A. Bryman, \& T. F. Liao (Eds.), The Sage Encyclopedia of Social Science Research Methods (Vol. 3, pp. 986-990). Thousand Oaks, CA: Sage Publications.

Gabridge, T., Gaskell, M., \& Stout, A. (2008). Information seeking through student's eyes: The MIT photo diary study. College \& Research Libraries, 69(6), 510-522.

Grays, L. J., Del Bosque, D., \& Costello, K. (2008). Building a better M.I.C.E. trap: Using virtual focus groups to assess subject guides for distance education students. Journal of Library Administration, 48(3), 431-453.

Henry, L., Antonovic, A., Buete, S., Deardorff, P., Docarmo, T., Gutierrez, P., . . Yim, E. (2010a). Improving student success: Researching how students use electronic library resources. Retrieved from http://digital.library.unt.edu/ark:/67531/metadc32899/?q=henry\%2C\%20lisa

Henry, L., Carlson, S., Cheatham, D., Gorby, M., Leach, M., McAllister, G., .. . Yazdanparast, A. (2010b). Improving student success: Researching how students use electronic library resources. Retrieved from http://digital.library.unt.edu/ark:/67531/metadc32898/?q=henry\%2C\%20lisa

Hobbs, K. \& Klare, D. (2010). User driven design: Using ethnographic techniques to plan student study space. Technical Services Quarterly, 27(4) 347-363. doi:10.1080/07317131003766009

Mann, B. (2011, June). The UMUC experience. Panel slides presented at the 2011 Annual Conference of the American Library Association, New Orleans, LA. Retrieved from http://connect.ala.org/node/137552\#comment-22192

Mays, N., \& Pope, C. (1995). Qualitative research: Rigour and qualitative research. British Medical Journal, 311(6997), 109-112. doi: 10.1136/bmj.311.6997.109.

Salmons, J. (2011). Cases in online interview research. Thousand Oaks, CA: Sage Publications.

Salmons, J. (2010). Online interviews in real time. Thousand Oaks, CA: Sage Publications. 
Schafer, S. (1998). Student satisfaction with library services: Results of evaluation using focus groups. In Thomas, P. S., \& Jones, M. (Eds.), The Eighth Off-Campus Library Services Conference Proceedings (pp. 245-250). Mount Pleasant, Michigan. Retrieved from http://ocls.cmich.edu/conference/past_proceedings/8thOCLSCP.pdf

Smale, M.A., \& Regalado, M. (2011). The scholarly habits of undergraduates at CUNY: Preliminary results. Retrieved from http://ushep.commons.gc.cuny.edu

Vehovar, V., Batagelj, Z., Lozar Manfreda, K., \& Zaletel, M. (2002). Nonresponse in web surveys. In R. M. Groves, D. A. Dillman, J. L. Eltinge, \& R. J. A. Little (Eds.), Survey nonresponse (pp. 229242). New York: John Wiley \& Sons.

Wahl, Diane. Assessment of library support for distance learning at UNT. Panel slides presented at the 2011 Annual Conference of the American Library Association, New Orleans, LA. Retrieved from http://connect.ala.org/node/137552\#comment-22192

Washburn, A. \& Bibb, S.C. (2011). Students studying students: An assessment of using undergraduate student researchers in an ethnographic study of library use. Library and Information Research 35(109), 55-66.

Webb, K. M, Schaller, M., \& Hunley, S. A. (2008), Measuring library space use and preferences: Charting a path toward increased engagement. Portal: Libraries and the academy, 8(4), 407-422. 


\section{Appendix A}

\section{Online Student Focus Group Invitation}
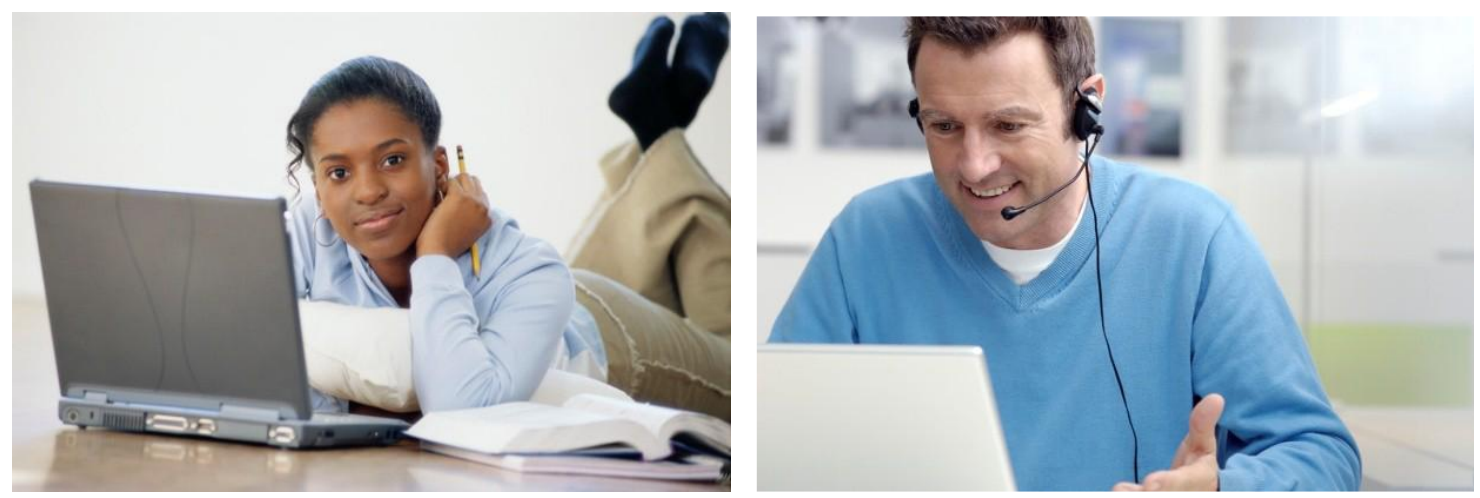

WHAT: Focus groups about library services for online students. Four groups of 5 to 8 students are planned.

WHO: Volunteers who represent the online student population at UNT:

- Graduate/undergraduate

- At least one student from each college or school

- International/local

- Under/over 30

- Beginning of program at UNT/end of program at UNT

- Male/female

WHEN: Now through August

- June/July - initial meeting of $1 \frac{1 / 2}{2}$ hours

- Website for ongoing communication regarding library planning to address issues identified, 2 to 3 hours between June/July and August/September

- August/September - follow up meeting of 1 hour to review library recommendations regarding services for online students.

WHERE: By conference call.

THANK YOU: Everyone who participates will receive a flash drive at the end of the first focus group.

HOW TO VOLUNTEER: Send an email before June 12 to diane.wahl@ unt.edu.

SPONSORED BY: UNT Libraries 


\section{Appendix B}

\section{ONLINE STUDENT FOCUS GROUP SCRIPT}

1. Tell us your name, your academic area, and where you are in your degree program.

2. What types of technology are you using?

Prompts:

a. Internet access (dial up, DSL, broadband wireless, cable Internet, WiFi, FTTH - fiber to the premises)

b. PC (laptop, desktop)

c. PDA (smartphone?)

d. Bluetooth enabled phones

e. Other?

3. What would you tell a new online/distance student about the library?

4. We'd like to know how you learn about library services and resources.

a. How do you currently find out about library services?

b. How would you like to find out about library services?

Prompts:

i. Email

ii. Library news items on web site home page

iii. Web page dedicated to online/distance students

iv. Webinar on online/distance student services

v. As part of one of your classes

vi. Other?

c. What is the easiest way for you to learn how to use the online library resources and services?

Prompts:

i. Online tutorials

ii. Webinars

iii. Librarian in the classroom

iv. Teaching yourself through hands-on experimentation

v. Other?

d. What kind of direction or instruction on using the library and library resources do you get from your professors?

5. Let's talk about your research process.

a. Where or how do you start your research?

b. What do you do next?

c. Does the library become involved?

Prompts:

i. What do you think of the online library catalog?

ii. How can the catalog be improved to help your research? Prompts: table of contents, book reviews, ratings similar to those in Amazon.com, images of book covers, etc.?

iii. How do you find journal articles?

iv. What other research tools do you use?

d. What do you do if you can't find what you're looking for?

e. What do you do if you need a book or journal article that isn't available online? 
6. Do you ever use a physical library, either at UNT or elsewhere? What kind of resources (physical or electronic) do you prefer to use?

7. Think back to an experience you had with a library that was outstanding. This experience may have taken place at the UNT Libraries or any other library. Describe it.

8. What else does the library you use do well?

9. What has been your greatest disappointment with UNT Libraries or any library that you use?

10. What else does the library you use need to improve?

11. Is there anything else you would like to tell us about using the UNT library or other libraries you use for your studies? 


\section{Appendix C}

\section{Observation Fieldnotes (Assignment \#3)}

Your assignment is to observe an online student conducting library research through the UNT library webpage. It's is very broad. Think about the goal of the research project and what our client wants us to find out. How are online students using library resources?

\section{Getting ready for the assignment:}

1. Recruit an online student who has some kind of assignment that requires library research.

2. Arrange a time to meet in your Live Classroom research room.

3. Provide the link and phone number to the participant in advance and ask them to run the setup wizard.

4. If they have a webcam then ask them to use it because you both will feel more connected during the observation. If they don't have a webcam then just use your webcam so the participant will feel connected to you.

5. At the scheduled meeting time, both of you enter Live Classroom and get connected.

6. When you get in to Live Classroom, click on the video recorder icon. A gray box will pop up. Click on the closed eye to turn on your webcam. You will want to move this video into a corner so that it does not block your view of the screen.

7. Click the archive button and MAKE SURE the session is being archived.

8. Click the share button. A window will pop up showing you the AppShare Status. You should see your name and your research participant's name.

9. Important step - next to your participant's name, click the box to give them cursor control and click the circle to indicate sharing desktop.

10. Click the orange begin sharing button.

11. At this point your participant should be given instructions on their screen about how to share their desktop. They need to expand the viewing window large enough so that you can see their entire desktop.

\section{Before you begin the observation, you should}

1. Read the informed consent notice to them. You can also email it to them before the meeting. If you do this, just make sure they understand all parts of the consent notice. Click here to print assess the informed consent notice.

2. Record a description of the research assignment and course

3. Record a description of what library research they have already done for this assignment (where are they in the process?)

4. Record where are they located at the moment of observation

a. (home, coffee shop, etc?)

5. Record the following demographic data

a. age

b. gender

c. marital status

d. ethnicity

e. children

f. employment status

g. other commitments

h. geographic location

i. disabilities that affect students' assess to library resources

(either on-campus or online)

j. average credit hours per semester

k. field of study / major / college

1. Has the student done academic research on the UNT website previously? 
m. Is English a foreign or secondary language to the student?

n. number of online courses student has previously enrolled in

o. What technology is the student currently using to conduct research?

(desktop, laptop, netbook, iPad, smart phone, eReader (Kindle)

\section{Doing the observation:}

1. You will ask your participant to narrate as they proceed with their research.

2. You shouldn't be asking lots of questions, but rather observing their actions.

3. Watch where they go first, maybe it's not the library website... maybe they go to Google Scholar first.

4. When they get to the library website, watch what they do first.

a. And then where do they go?

b. What kinds of key words are they entering?

c. How are they getting their information?

d. Do they create an electronic file for all of their information? (you will be able to see this because you can see their entire computer screen)

e. Are they writing it down by hand?

f. What kinds of files are they accessing?

5. You want to observe and record everything that you possibly can about that library research. From reading your brainstorming activities, I know you guys have really thought about this process.

6. You can ask them clarifying questions like "why did you go there?" "are you writing anything down with pen and paper?"

You must observe for at least 30 minutes.

Be VERY descriptive. Be very thorough in your descriptions. Make sure those details are in your fieldnotes.

\section{Write Up}

For the write up - there isn't one style of write-up. Everyone has their own styles and I'll let you experiment with this. Check out the "sample fieldnotes" example that I handed out in class.

There also isn't specific page length, but it should be more than just a few pages. When you are doing ethnography you need to write until you're done taking notes... until you're done with the assignment. The more descriptive, the better.

One thing specific that I want you to do with the write-up is write a SUMMARY section. I want you to summarize the behaviors that you recorded. What can you say in general about the observation? Is their one pattern of behavior? Two patterns of behavior? Put it into a neat summary package. This will make analysis at the end of the project much easier.

Post any questions you have to the discussion board topic "Observation Assignment" under Project Discussions.

This assignment is due on Oct. 22 ${ }^{\text {nd }}$ (a Friday). Submit to the assignment tool. 